\title{
Studies on Effect of Fermentation on Physicochemical Properties of Vegetables and Preparation of Sauce
}

\author{
P.P. Thorat ${ }^{*}$, S.K. Sadawarte, A.R. Sawate and G.M. Machewad \\ College of Food Technology, Vasantrao Naik Marathwada Krishi Vidyapeeth, \\ Parbhani (MH), India \\ *Corresponding author
}

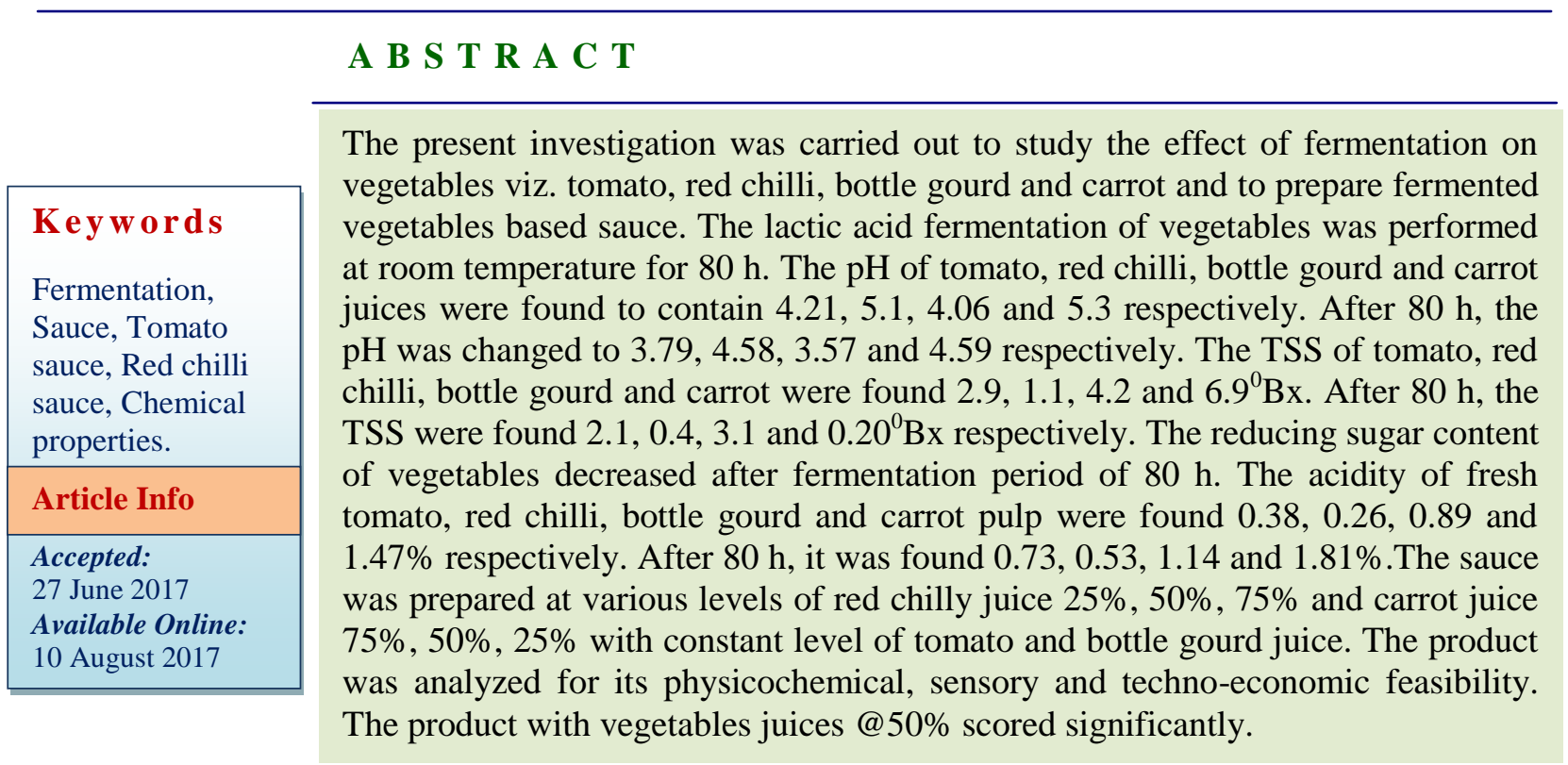

\section{Introduction}

Fermentation is one of the oldest forms of food preservation technologies in the world (Battcock and Azam-Ali, 1998).By tradition, lactic acid bacteria (LAB) are the most commonly used microorganisms for preservation of foods. Their importance is associated mainly with their safe metabolic activity while growing in foods utilizing available sugar for the production of organic acids and other metabolites (Balasubramanyam and Varadaraj, 1995). Lactic acid bacteria are a group of grampositive, non-spore forming, cocci or rods which produce lactic acid as the major end product during the fermentation of carbohydrates. Lactic acid bacteria are a small part of the autochthonous microbiota of vegetables and fruits. Lactic acid bacteria have been used in the production of foods, especially fermented foods because they can produce several compounds that contribute to taste, smell, color and texture of the foods.

In addition, they can produce antimicrobial substances including bacteriocins that have ability to inhibit pathogenic and food spoilage bacteria (Rattanachaikunsopon and Phumkhachorn, 2010). 
The nutritional impact of fermented foods on nutritional diseases can be direct or indirect. Food fermentations that increase the protein content or improve the balance of essential amino acids or their availability will have a direct curative effect.

Similarly fermentations that increase the content or availability of vitamins such as thiamine, riboflavin, niacin or folic acid can have profound direct effects on the health of the consumers of such foods (Steinkraus, 1997). Fermented foods may reduce the serum cholesterol concentration by reducing the intestinal absorption of dietary and endogenous cholesterol or inhibiting cholesterol synthesis in liver (Kalantzopoulos, 1997).

Lactic acid may also lower the gut $\mathrm{pH}$ therefore inhibiting development of putrefactive bacteria (Manning et al., 2004). Fermented vegetables are a source of dietary fiber which impedes assimilation of fats and regulates peristalsis of intestine. They are also a valuable source of vitamin $\mathrm{C}$ and $\mathrm{B}$-group vitamin, phenolic and many other nutrients present in raw material. Fermented vegetables are perceived as suitable product for introducing $\mathrm{LAB}$ with probiotic properties into the human diet (Caplice and Fitzgerald, 1999; Yoon et al., 2005).

Tomato is among a fruit of the numerous cultivated varieties of solanum lycopersicum formerly lycopersicon esculentum. Tomato fruit is a rich source of ascorbic acid (vitamin C). The red color of tomatoes is a result of the degradation of chlorophylls and the increased biosynthesis of carotenoids, thus it is related to the degree of maturity and postharvest life (Harris and Spurr, 1969).The nutritional significance of lycopene, a carotenoid with potent antioxidant activity has been reported and accumulating evidence has shown an inverse correlation between the consumption of tomato products rich in lycopene and the risk of several types of cancer and cardiovascular disease (Rao and Agarwal, 1999; Giovannucci, 2005; Talvas et al., 2010).Red chilli (Capsicum annuum) belongs to the genus Capsicum under Solanaceae family. Chilli besides imparting pungency and red color to the dishes, it is rich source of vitamin $\mathrm{A}, \mathrm{C}$ and $\mathrm{E}$ and assists in digestion. Recently, Russian scientists have identified Vitamin P in green chilli which is considered as important to protect from secondary irradiation injury (Parle and Kaur, 2012).

The Lagenaria siceraria of family Cucurbitaceae known as bottle gourd, Doodhi and Lauki. Other than the provision of essential fatty and amino acids, the young edible fruits of bottle gourd are rich in dietary fiber with very low fat and cholesterol levels and have about $80 \%$ water content in its flesh. Carrot (Daucus carota L.) is a root vegetable described as an edible, reddish yellow and fusiform root. It is the rich source of vitamin A and iron.

It increases the quantity of urine and helps the elimination of uric acid. Increase in the quantity of carrot in the diet has a favorable effect on the nitrogen balance. It cures leprosy, piles pins, burning sensation, thirst, biliousness and tumours. Carrots are aromatic, stimulant, carminative and are useful in the diseases of the kidney and dropsy (De and Parikh, 1985).

The aim of the present study was to utilize the highly perishable vegetable for processing into a value added food products because of their nutritional significance. The fermentation process will improve the nutritional compositional and sensory quality with improved digestibility. It also increases the shelf life of prepared products. It will help in throughout year availability of vegetables in the form of value added products. 


\section{Materials and Methods}

The present investigation was carried out in College of Food Technology, Vasantrao Naik Marathwada Krishi Vidyapeeth, Parbhani (MH) India. The tomato (Vasundhara (HY28)), red chilli (Jwala), bottle guard (Arka Bahar) and carrot (Pusa Kesar) which are fully matured, healthy and uniform size were selected. The starter cultures Lactobacillus plantarum, Pediococcus acidilactici, Streptococcus lactis, Lactopbacillus brevis, Lactobacillus pentosus, Leuconostoc mesenteroid and Lactobacillus fermentum were used for the fermentation. The fermentation was conducted at $20-30^{\circ} \mathrm{C}$ in brine containing $3 \%$ salt. Fermented vegetables were converted into paste/pulp by adding water in 1:1 ratio in a mixer and used for sauce preparation. The fermented red chilly and carrot pulp were mixed in different ratios $\left(\mathrm{T}_{1}: 25 \%\right.$ Fermented red chilly $+75 \%$ Fermented carrot pulp; $\mathrm{T}_{2}: 50 \%$ Fermented red chilly $+50 \%$ Fermented carrot pulp; $\mathrm{T}_{3}$ : $75 \%$ Fermented red chilly $+25 \%$ Fermented carrot pulp).

Sauce was prepared from fermented vegetables as per the standard procedure given by Lal et al., (1960).In the preparation of sauce paste/pulp $(1 \mathrm{~kg})$ was heated slowly and the spice bag containing $10 \mathrm{~g}$ of coarsely ground cardamom, black pepper, cumin, powdered red chilies, cloves and finely chopped onion (100 g), and garlic (20 g) were placed in paste/pulp during boiling. About $1 / 3^{\text {rd }}$ of sugar $(180 \mathrm{~g})$ was added at the time of commencing the boiling. The rest of sugar (37 g) was added a little before the sauce was ready. Salt $(10 \mathrm{~g})$ was also added towards the end of boiling. Before adding salt, spice bag was taken out. When the sauce was ready i.e. attained total soluble solids (TSS) $17^{\circ} \mathrm{B}$, sodium benzoate $(750 \mathrm{ppm})$ and acetic acid (3 $\mathrm{ml} / \mathrm{kg}$ or little more as required) were added so that the final product contains more than $1.2 \%$ acidity as acetic acid. The sauce was hot filled in pre-cleaned, sterilized, dry glass bottles of $200 \mathrm{ml}$ capacity. Bottles were crown corked and stored at ambient temperature $\left(15-28^{\circ} \mathrm{C}\right)$.

\section{Physicochemical Analysis}

The physicochemical analysis of sauce was carried out by AOAC, 1990.

\section{Sensory evaluation}

The sauce was evaluated for sensory characteristics by panel members on 9-point Hedonic scale.

\section{Results and Discussion}

Effect of fermentation on physicochemical properties of tomato, red chilli, bottle gourd and carrot

The starter cultures Lactobacillus plantarum 2083, Pediococcus acidilactici 2171, Streptococcus lactis 2606, Lactopbacillus brevis 2090, Lactobacillus pentosus 2669, Leuconostoc mesenteroid 2073, Lactobacillus fermentum 2165 were purchased from National Chemical Laboratory, NCIM, Pune.

The starter culture selected based on the rates of growth and acidification in vegetables juice media and used as the mixed starter for the fermentation of tomato, red chilli, bottle gourd and carrot (Di Cagno et al., 2008).

\section{Effect of fermentation on $\mathrm{pH}$ of vegetables}

The $\mathrm{pH}$ of tomato, red chilli, bottle gourd and carrot juice were found to contain 4.21, 5.1, 4.06 and 5.3 respectively (Table 1 ). After fermentation of $80 \mathrm{~h}$, the $\mathrm{pH}$ was changes to $3.79,4.58,3.57$ and 4.59 respectively. The reduction of $\mathrm{pH}$ and removal of a large amount of carbohydrates by fermentation are the primary preserving actions that these bacteria. 
Mao et al., (2013) reported that at the start of fermentation, microorganism such as lactic acid bacteria decomposed carbohydrates and fats to produce small molecule organic acids such as lactic acid, acetic, decomposed the protein to produce free amino acid, which reduces $\mathrm{pH}$ of vegetable juices.

\section{Effect of fermentation on Total Soluble Solid (TSS) of vegetables}

The TSS of tomato, red chilli, bottle gourd and carrot juice were found 2.9, 1.1, 4.2 and $6.9^{0} \mathrm{Bx}$. After fermentation of $80 \mathrm{~h}$, the TSS of tomato, red chilli, bottle gourd and carrot juice were found $2.1,0.4,3.1$ and $0.20^{\circ} \mathrm{Bx}$ respectively (Table 2). The TSS of vegetables was found to decrease during fermentation because of the effect of initial microbial load. The sugar in vegetables might be utilized by microbes during fermentation process which ultimately resulted in decrease in TSS.

\section{Effect of fermentation on reducing sugar content of vegetables}

The reducing sugar content of raw vegetables juice viz. tomato, red chilli, bottle gourd and carrot juice was $0.0075,0.0055,0.0094$ and $0.0101 \mathrm{mg} / 100 \mathrm{~g}$ respectively (Table 3 ). After fermentation of $80 \mathrm{~h}$ the reducing sugar content of vegetables decreased i.e. 0.0047, $0.0038, \quad 0.0060$ and $\quad 0.0071 \mathrm{mg} / 100 \mathrm{~g}$ respectively. The vegetables juice viz. tomato, red chilli, bottle gourd and carrot have a different content of reducing sugars expressed as glucose. Reducing sugar is a downward trend during fermentation (Manea and Buruleanu, 2010).

It was clear that due to the amylolytic activity of microbial strains used for fermentation. A part of the starch in vegetables was converted to sugar and consequently to lactic acid during organic acid metabolism (Giraud et al., 1993; Zhang et al., 2000). However, all the fermentable sugars generated did not convert to lactic acid; a substantial portion had been probably utilized by microorganism present in the fermentation medium for their normal metabolism (Montet et al., 2006).

\section{Effect of fermentation on acidity of vegetables}

The acidity of fresh tomato, red chilli, bottle gourd and carrot juice were found 0.38, 0.26, 0.89 and $1.47 \%$ respectively (Table 4 ). After fermentation period of $80 \mathrm{~h}$, acidity of tomato, red chilli, bottle gourd and carrot were found $0.73,0.53,1.14$ and $1.81 \%$.

The increase in titratable acidity of tomato, chilli, bottle gourd and carrot was inversely proportional to the increase in salt concentration in the brine solution. A rapid increase in acidity in fermented vegetables is associated with the increase in organic acids mainly lactic acid which also minimizes the influence of spoilage bacteria (Adams and Nicolaides, 1997; Liu, 2003; Montet et al., 2006).

Table.1 Effect of fermentation on $\mathrm{pH}$ of tomato, red chilli, bottle gourd and carrot juice

\begin{tabular}{|c|c|c|c|c|c|c|c|c|}
\hline \multirow[t]{3}{*}{ Vegetables } & \multicolumn{6}{|c|}{$\mathbf{p H}$} & \multirow[t]{3}{*}{ SE \pm} & \multirow{3}{*}{$\begin{array}{l}\text { CD@ } 5 \% \\
\text { level }\end{array}$} \\
\hline & \multicolumn{6}{|c|}{ Fermentation time (h) } & & \\
\hline & 0 & 20 & 40 & 60 & 70 & 80 & & \\
\hline Tomato & 4.21 & 4.18 & 4.08 & 3.96 & 3.86 & 3.79 & 0.07 & 0.14 \\
\hline Red chilli & 5.10 & 4.96 & 4.88 & 4.77 & 4.64 & 4.58 & 0.08 & 0.16 \\
\hline Bottle gourd & 4.06 & 3.97 & 3.86 & 3.75 & 3.68 & 3.57 & 0.07 & 0.15 \\
\hline Carrot & 5.30 & 4.96 & 4.87 & 4.73 & 4.68 & 4.59 & 0.10 & 0.20 \\
\hline
\end{tabular}


Table.2 Effect of fermentation on TSS of tomato, chilli, bottle gourd and carrot juice

\begin{tabular}{|c|c|c|c|c|c|c|c|c|}
\hline \multirow[t]{3}{*}{ Vegetables } & \multicolumn{6}{|c|}{ Fermentation time (h) } & \multirow[t]{3}{*}{ SE \pm} & \multirow{3}{*}{$\begin{array}{l}\text { CD at } \\
5 \% \text { level }\end{array}$} \\
\hline & \multicolumn{6}{|c|}{ TSS $\left({ }^{0} \mathbf{B x}\right)$} & & \\
\hline & 0 & 20 & 40 & 60 & 70 & 80 & & \\
\hline Tomato & 2.9 & 2.6 & 2.5 & 2.4 & 2.2 & 2.1 & 0.11 & 0.23 \\
\hline Red chilli & 1.1 & 0.9 & 0.8 & 0.7 & 0.6 & 0.4 & 0.09 & 0.19 \\
\hline Bottle gourd & 4.2 & 3.9 & 3.7 & 3.4 & 3.2 & 3.1 & 0.17 & 0.34 \\
\hline Carrot & 6.9 & 6.4 & 6.2 & 5.9 & 5.7 & 5.5 & 0.20 & 0.41 \\
\hline
\end{tabular}

Table.3 Effect of fermentation on reducing sugar content of Tomato, red chilli, bottle gourd and carrot juice

\begin{tabular}{|l|l|l|l|l|l|l|l|}
\hline \multirow{2}{*}{ Vegetables } & \multicolumn{4}{|c|}{ Fermentation time (h) } & \multirow{2}{*}{ SE \pm} & CD at \\
\cline { 2 - 6 } & \multicolumn{4}{|c|}{ Reducing sugar (mg/100 g) } \\
\cline { 2 - 6 } & 0 & 20 & 40 & 60 & 80 & & level \\
\hline Tomato & 0.0075 & 0.0068 & 0.0059 & 0.0052 & 0.0047 & 0.0005 & 0.11 \\
\hline Red chilli & 0.0055 & 0.0051 & 0.0046 & 0.0042 & 0.0038 & 0.0003 & 0.07 \\
\hline Bottle gourd & 0.0094 & 0.0087 & 0.0078 & 0.0066 & 0.0060 & 0.0006 & 0.14 \\
\hline Carrot & 0.0101 & 0.0096 & 0.0085 & 0.0079 & 0.0071 & 0.0005 & 0.12 \\
\hline
\end{tabular}

Table.4 Effect of fermentation on acidity of tomato, red chilli, bottle gourd and carrot juice

\begin{tabular}{|c|c|c|c|c|c|c|c|c|}
\hline \multirow[t]{3}{*}{ Vegetables } & \multicolumn{6}{|c|}{ Fermentation time (h) } & \multirow[t]{3}{*}{ SE \pm} & \multirow{3}{*}{$\begin{array}{l}\text { CD a } \\
5 \% \\
\text { level }\end{array}$} \\
\hline & \multicolumn{6}{|c|}{ Acidity (\%) } & & \\
\hline & 0 & 20 & 40 & 60 & 70 & 80 & & \\
\hline Tomato & 0.38 & 0.41 & 0.47 & 0.56 & 0.67 & 0.73 & 0.05 & 0.11 \\
\hline Red chilli & 0.26 & 0.31 & 0.36 & 0.40 & 0.49 & 0.53 & 0.04 & 0.08 \\
\hline Bottle gourd & 0.89 & 0.93 & 0.98 & 1.04 & 1.08 & 1.14 & 0.03 & 0.08 \\
\hline Carrot & 1.47 & 1.52 & 1.59 & 1.64 & 1.73 & 1.81 & 0.05 & 0.1 \\
\hline
\end{tabular}

Table.5 Effect of fermentation on nutritional content of Tomato, red chilli, bottle gourd and carrot juice

\begin{tabular}{|l|l|l|l|l|l|l|}
\hline \multirow{2}{*}{ Vegetables } & \multicolumn{3}{|c|}{ Before fermentation } & \multicolumn{3}{c|}{ After fermentation } \\
\cline { 2 - 7 } & $\begin{array}{l}\text { Protein } \\
(\boldsymbol{\%})\end{array}$ & $\begin{array}{l}\text { Carbohydrate } \\
(\mathbf{\%})\end{array}$ & $\begin{array}{l}\text { Vit C } \\
(\mathbf{m g} / \mathbf{1 0 0 g})\end{array}$ & $\begin{array}{l}\text { Protein } \\
(\boldsymbol{\%})\end{array}$ & $\begin{array}{l}\text { Carbohydrate } \\
(\mathbf{\%})\end{array}$ & $\begin{array}{l}\text { Vit C } \\
(\mathbf{m g} / \mathbf{1 0 0 g})\end{array}$ \\
\hline Tomato & 0.79 & 3.48 & 13.7 & 1.93 & 2.76 & 20.8 \\
\hline Red chilli & 0.95 & 3.94 & 30.08 & 1.23 & 2.84 & 35.6 \\
\hline Bottle gourd & 1.27 & 3.78 & 12.2 & 2.35 & 2.31 & 15.7 \\
\hline Carrot & 0.97 & 5.87 & 5.87 & 1.84 & 4.62 & 7.93 \\
\hline
\end{tabular}


Table.6 Physicochemical characteristics of lactic acid fermented vegetables based sauce

\begin{tabular}{|l|c|c|c|}
\hline \multirow{2}{*}{ Parameters } & \multicolumn{3}{|c|}{ Samples } \\
\cline { 2 - 4 } & $\mathbf{T}_{\mathbf{1}}$ & $\mathbf{T}_{\mathbf{2}}$ & $\mathbf{T}_{\mathbf{3}}$ \\
\hline TSS ( $\left.{ }^{0} \mathrm{Bx}\right)$ & 18 & 18 & 3.4 \\
\hline $\mathrm{pH}$ & 3.3 & 3.5 & 1.29 \\
\hline Acidity (\%) & 1.31 & 1.28 & 13.95 \\
\hline Brix/acid ratio & 13.74 & 14.06 & $21.6 \pm 0.2$ \\
\hline \begin{tabular}{c} 
Color value \\
\multicolumn{1}{c|}{$\mathrm{a}$}
\end{tabular} & $21.3 \pm 0.3$ & $22.1 \pm 0.3$ & $31.6 \pm 0.2$ \\
& $30.4 \pm 0.4$ & $31.7 \pm 0.3$ & $13.72 \pm 0.4$ \\
\hline Viscosity (cP) & $13.44 \pm 0.4$ & $13.3 \pm 0.3$ & 2600 \\
\hline Salt (\%) & 2600 & 2600 & 2.3 \\
\hline Total sugar (\%) & 2.19 & 2.1 & 11.73 \\
\hline Reducing sugar & 12.15 & 12.99 & 0.0021 \\
(mg/100g) & 0.0022 & 0.0023 & 4.14 \\
\hline Protein (\%) & & & 0.094 \\
\hline Carbohydrate (\%) & 0.089 & 4.16 & 4.11 \\
\hline $\begin{array}{l}\text { Ascorbic acid } \\
\text { (mg/100g) }\end{array}$ & 4.12 & 0.092 & 11428 \\
\hline Turbidity (NTU) & 11429 & 4.13 & \\
\hline
\end{tabular}

$\mathrm{T}_{1}: 25 \%$ Fermented red chilly $+75 \%$ Fermented carrot pulp

$\mathrm{T}_{2}: 50 \%$ Fermented red chilly $+50 \%$ Fermented carrot pulp

$\mathrm{T}_{3}: 75 \%$ Fermented red chilly $+25 \%$ Fermented carrot pulp

Table.7 Sensory evaluation of lactic acid fermented mixed vegetables sauce

\begin{tabular}{|l|l|l|l|l|l|}
\hline \multicolumn{1}{|c|}{ Samples } & Color & Consistency & Flavor & Taste & Overall acceptability \\
\hline Control & 8.1 & 8.2 & 8.2 & 8.3 & 8.1 \\
\hline $\mathbf{T}_{\mathbf{1}}$ & 7.1 & 7.1 & 7.2 & 7.3 & 7.3 \\
\hline $\mathbf{T}_{\mathbf{2}}$ & $\mathbf{8 . 2}$ & $\mathbf{8 . 3}$ & $\mathbf{8 . 3}$ & $\mathbf{8 . 3}$ & $\mathbf{8 . 2}$ \\
\hline $\mathbf{T}_{\mathbf{3}}$ & 7.8 & 7.4 & 7.5 & 7.7 & 7.8 \\
\hline
\end{tabular}

$\mathrm{T}_{1}: 25 \%$ Fermented red chilly $+75 \%$ Fermented carrot pulp

$\mathrm{T}_{2}: 50 \%$ Fermented red chilly $+50 \%$ Fermented carrot pulp

$\mathrm{T}_{3}: 75 \%$ Fermented red chilly $+25 \%$ Fermented carrot pulp

Effect of fermentation on nutritional composition of vegetables

The fresh tomato juice was found to contain protein $(0.79 \%)$, carbohydrate $(3.48 \%)$ and ascorbic acid (13.7 $\mathrm{mg} / 100 \mathrm{~g})$. After fermentation period of $80 \mathrm{~h}$, the tomato juice was found to contain protein (1.93\%), carbohydrate $(2.76 \%)$ and ascorbic acid $(20.8$ $\mathrm{mg} / 100 \mathrm{~g})$. The red chilli was found to contain protein $(0.95 \%)$, carbohydrate $(3.94 \%)$ and ascorbic acid (30.08 $\mathrm{mg} / 100 \mathrm{~g})$. After fermentation of chilli juice were found to contain protein (1.23\%), carbohydrate $(2.84 \%)$ and ascorbic acid (35.60 mg/100g).

The fresh bottle gourd pulp was found to contain protein (1.27\%), carbohydrate $(3.78 \%)$ and ascorbic acid $(12.2 \mathrm{mg} / 100 \mathrm{~g})$. After fermentation period of $80 \mathrm{~h}$, protein was 
found $2.35 \%$, carbohydrate $(2.31 \%)$ and ascorbic acid $(15.7 \mathrm{mg} / 100 \mathrm{~g})$. The carrot juice was found to contain protein $(0.97 \%)$, carbohydrate $(9.39 \%)$ and ascorbic acid $(5.87$ $\mathrm{mg} / 100 \mathrm{~g})$. After fermentation period $(80 \mathrm{~h})$ the carrot juice were found to contain protein $(1.84 \%)$, carbohydrate $(4.62 \%)$ and ascorbic acid $(7.93 \mathrm{mg} / 100 \mathrm{~g})$ (Table 5).

Nout and Ngoddy (1997) reported that the lactic acid fermentation enhances protein solubility and the availability of limiting amino acids in some cases by as much as $50 \%$. The micronutrient availability is also enhanced because of significant reductions in phytates.

The decrease in carbohydrate content of the fermented samples is due to the usual conversion of carbohydrate to ethanol during the process of fermentation. They protect the body against esophagus cancer, oral cavity and stomach; it also helps to maintain the blood vessel flexibility and improves circulation in the arteries of the smokers (Block et al., 1992). Fermentation caused a significant increase in the vitamin $\mathrm{C}$ content (Oboh et al., 2011).

\section{Physicochemical analysis of sauce}

The lactic acid fermented vegetables based sauce was analyzed for its physicochemical parameters. The sample $\mathrm{T}_{2}$ were found to contain TSS (180Bx), pH (3.5), Acidity (1.28 $\%$ ), Brix/Acid Ratio (14.06), Color (L: $22.1 \pm$ 0.3 , a: $31.7 \pm 0.3$, b: $13.3 \pm 0.3)$, Viscosity $(2600 \mathrm{cP})$, salt $(2.1 \%)$, total sugar $(12.99 \%)$, reducing sugar $(0.0023 \mathrm{mg} / 100 \mathrm{~g})$, protein (4.16\%), carbohydrate $(0.092 \%)$, Vitamin C (4.13 mg/100g), turbidity (11432 NTU).

The physicochemical properties of $T_{1}$ and $T_{3}$ were described in table 6 . The results obtained were similar to the findings of Joshi and Sharma (2010).

\section{Sensory evaluation}

The sauce was served to judges on the day of preparation. The average score of samples by judges were presented in table 7. The sample B scored higher for all sensory parameters.

\section{Cost economy}

The ingredients needed for the preparation of fermented vegetables based sauce were rated as per the prevailing market price. The cost of production of samples $\mathrm{T}_{1}, \mathrm{~T}_{2}$ and $\mathrm{T}_{3}$ were found Rs. 71.962, 80.712 and 89.462 respectively. The variation in cost structure is because of the amount of red chilli and carrot.

From the above investigation it could be concluded that, the chemical constituents of these vegetables were increased due to the fermentation process. Fermentation increases the nutritional value of finished product. The nutritional value and palatability was improved by fermentation. Sugar concentration and $\mathrm{pH}$ was found to decrease proportionally with the increase in the duration of fermentation. Sample B prepared with $50 \%$ red chilli juice and 50\% carrot juice found organoleptically accepted.

\section{References}

Adams, M.R., and Nicolaides, L. 1997. Review of the sensitivity of different food borne pathogens to fermentation. Food Control.8, 227-239.

Balasubramanyam, B.V., and Varadaraj, M.C. 1995. Antibacterial effect of Lactobacillus sp on food borne pathogenic bacteria in an Indian milk based fermented culinary food item. Cultured Dairy Prod. J. 30, 22-24.

Battcock, M., and Azmi-ali, S. 1998. Fermented fruits and vegetables. In: fermented fruits and vegetables. A global perspective. FAO Agricultural 
services bulletin No 134, Food and Agriculture Organization of the United Nations, Italy, Rome.

Block, G., Patterson, B. and Subar, A. 1992. Fruits vegetables and cancer prevention. A review of epidemiological evidence. Nutr. Cancer.18, 1-29.

Caplice, E., and Fittzgerald, G.F. 1999. Food fermentations: role of microorganisms in food production and preservation.Int. J. Food Microbiol. 50(1/2): 131-149.

De, S., and Parikh, K.M. 1985. Medicinal importance of some common Indian vegetables part I. Ancient Science of Life.4 (4): 232-237.

Di Cagno, R., Surico, R.F., Siragusa, S., De Angelis, M., Paradiso, A., Minervini, F., De Gara, L. and Gobbetti, M. 2008. Selection and use of autochthonous mixed starter for lactic acid fermentation of carrots, French beans or marrows. Int. J. Food Microbiol. 127, 220-228.

Giovannucci, E., 2005. Tomato products, lycopene and prostate cancer: A review of the epidemiological literature. J. Nutr. 135, 2030-2031.

Giraud, E., Brauman, A., Marin, B., Pararada, J.L. and Raimbault, M. 1993. Purification and characterization of an extracellular amylase from Lactobacillus plantarum strain A6. J. Appl. Bacteriol.75, 276-283.

Harris, W.M., and Spurr, A.R. 1969. Chromoplasts of tomato fruits-II. The red tomato. Am. J. Bot. 56, 380-389.

Joshi, V.K., and Sharma, S. 2010. Preparation and evaluation of sauces from lactic acid fermented vegetables. J. Food Sci. Technol. 47, 214-218.

Kalantzopoulos, G., $1997 . \quad$ Fermented products with probiotic qualities. Anaerobe.3, 185-190.

Manea, I., Buruleanu, L.C. and Ploscutanu, G. 2013. The evaluation of lactic fermentation yield of carrot juice with different additives. Anal. Food Sci. Technol.14 (1): 34-38.

Manning, T.S., Rastall, R. and Gibson, G. 2004. Prebiotics and lactic acid bacteria. In: Lactic acid bacteria. Microbiological and functional aspects (eds. S. Salminen, A. von Wright, A. Ouwehand). Marcel Dekker, Inc., New York, Basel, pp. 407-418.

Mao, C., He, G., Du, X., Cui, M. and Gao, S. 2013. Biochemical changes in the fermentation of the soy sauce prepared with bittern. Adv. J. Food Sci. Technol. 5(2): 144-147.

Montet, D., Loiseau, G. and Zakhia-Rozis, N. 2006. Microbial technology of fermented vegetables. In: Ray R. C. and Ward O. P. (Eds.), Microbial Biotechnology in Horticulture. Science Publishers Inc., Enfield, NH, pp. 309343.

Nout, M.J.R., and Ngoddy, P.O. 1997. Technological aspects of preparing affordable fermented complementary foods. Food Control. 8, 279-287.

Oboh, G., Ademosun, A.O., Adefegha, S.A. and Lajide, L. 2011. Enhancement of antioxidant properties and neuroprotective potentials of citrus peels using Aspergillus niger solid substrate fermentation technology. Ferm. Technol. Bioengg. 1, 49-61.

Olliver, M., 1967. Occurrence in foods. In: The Vitamins, W.H. Sebrell and R.S. Harris, eds., Vol. 1, pp. 359-367, Academic Press, New York.

Parle, M., and Kaur, S. 2011. Is bottle gourd a natural gourd?? Int. Res. J. Pharm. 2(6): 13-17.

Rao, A.V., and Agarwal, S. 1999. Role of lycopene as antioxidant carotenoid in the prevention of chronic diseases: A review. Nutr. Res.19, 305-323.

Rattanachaikunsopon, P., and Phumkhachorn, P. 2010. Lactic acid bacteria: their antimicrobial compounds and their uses 
in food production. Anal. Biol. Res. 1(4): 218-228.

Steinkraus, K.H., 1997. Classification of fermented foods: worldwide review of household fermentation techniques. Food Control.8, 311-317.

Talvas, J., Caris-Veyrat, C., Guy, L., Rambeau, M., Lyan, B. and MinetQuinard, R. 2010. Differential effects of lycopene consumed in tomato paste and lycopene in the form of a purified extract on target genes of cancer prostatic cells. Am. J. Clin. Nutr.91, $1716-1724$.

Yoon, K.Y., Woodams, E.E. and Hang, Y.D. 2004.Probiotication of tomato juice by lactic acid bacteria. J. Microbiol. 42(4): 315-318.

Zhang, J.H., Hu, F. and Chen, H.Y. 2000. Processing technique of vegetable juice beverage of sechium edule swartz and fermentation beverage of cucurbita moschata. Duch. J. Shanghai Agric. Coll. 18(2): 114-117.

\section{How to cite this article:}

Thorat, P.P., S.K. Sadawarte, A.R. Sawate and Machewad, G.M. 2017. Studies on Effect of Fermentation on Physicochemical Properties of Vegetables and Preparation of Sauce. Int.J.Curr.Microbiol.App.Sci. 6(8): 3537-3545. doi: https://doi.org/10.20546/ijcmas.2017.608.423 